Revista de Derecho Público: Teoría y Método Marcial Pons Ediciones Jurídicas y Sociales Vol. 4 | 2021 pp. 153-180 Madrid, 2021

DOI:10.37417/RPD/vol_4_2021_661

(C) Fernando Pastor Merchante

Recibido: 03/09/2021 | Aceptado: 15/10/2021 Editado bajo licencia Creative Commons Attribution 4.0 International License.

\title{
¿POR QUÉ LO LLAMAN PROCEDIMIENTO CUANDO QUIEREN DECIR EXPEDIENTE? SOBRE LAS FUNCIONES DOGMÁTICAS DEL EXPEDIENTE ADMINISTRATIVO
}

\section{WHY DO THEY CALL IT PROCEDURE WHEN THEY MEAN FILE? ON THE DOGMATIC FUNCTIONS OF THE ADMINISTRATIVE FILE}

\author{
Fernando Pastor Merchante \\ Profesor de Derecho Administrativo \\ IE Universidad \\ fernando.pastor@ie.edu \\ https://orcid.org/0000-0001-9503-6601
}

RESUMEN: La tesis de este trabajo es que el expediente administrativo merece mayor atención por parte de la dogmática del derecho administrativo. Para sustentar esta tesis, el trabajo analiza las distintas funciones que el expediente administrativo desempeńa tanto en la dirección como en el control de legalidad de la acción administrativa. Además, el trabajo muestra que una mayor atención por el expediente administrativo como eslabón intermedio entre el procedimiento y la resolución administrativa puede contribuir a enriquecer la teoría de los vicios de procedimiento y la teoría del control de la discrecionalidad.

PALABRAS CLAVE: Procedimiento administrativo; expediente administrativo; vicios de procedimiento; buena administración; discrecionalidad administrativa; Administración electrónica.

* Este trabajo se enmarca dentro de las actividades de investigación de la Cátedra Pérez-Llorca/IE de la Escuela de Derecho de IE Universidad.

En el texto se emplean las siguientes abreviaturas: LJCA - Ley 29/1998, de 13 de julio, reguladora de la Jurisdicción Contencioso-administrativa; LPAC - Ley 39/2015, de 1 de octubre, del Procedimiento Administrativo Común de las Administraciones Públicas. 
ABSTRACT: The thesis of this paper is that the administrative file deserves closer attention by legal scholarship. In order to support this thesis, the paper analyses the different functions that the administrative file plays both in the direction and review of administrative action. The paper argues that paying closer attention to the administrative file can contribute to a better understanding of key issues of contemporary administrative law, such as the theory on procedural errors and the theory on administrative discretion.

KEYWORDS: Administrative procedure; administrative file; procedural errors; good administration; administrative discretion; electronic administration.

SUMARIO: 1 . INTRODUCCIÓN.-2. EL CONCEPTO DE EXPEDIENTE ADMINISTRATIVO: CONCEPCIÓN DOCUMENTAL Y MATERIAL.-3. EL EXPEDIENTE ADMINISTRATIVO COMO INSTRUMENTO DE DIRECCIÓN Y CONTROL DE LA ACCIÓN ADMINISTRATIVA.-4. EL EXPEDIENTE ADMINISTRATIVO Y LA TEORÍA DE LOS VICIOS DE PROCEDIMIENTO.- 5. EL EXPEDIENTE ADMINISTRATIVO Y LA TEORÍA DEL CONTROL DE LA DISCRECIONALIDAD.-6. CONCLUSIÓN.-7. BIBLIOGRAFÍA.

\section{INTRODUCCIÓN}

Tradicionalmente, la dogmática del derecho administrativo se ha construido en torno a la doctrina de las formas, según la cual el mejor eje teórico de explicación de la disciplina son las formas básicas de actuación de la Administración: el acto, el contrato, y el reglamento. De entre estas formas, la que ha ocupado siempre un lugar preeminente es el acto administrativo, concepto fundamental de la disciplina a través del cual se han teorizado y articulado las exigencias del Estado de derecho ${ }^{1}$.

Es cierto que durante las últimas décadas se ha producido un cierto desplazamiento de la doctrina de las formas y de la centralidad del acto administrativo para la dogmática del derecho administrativo. Por un lado, la literatura ha constatado las limitaciones de las que adolece la doctrina de las formas y del acto administrativo para explicar algunos fenómenos contemporáneos, como el repliegue de las técnicas administrativas de control ex ante y la expansión de las técnicas de control expost ${ }^{2}$, la importancia de la inspección y la supervisión administrativas como actividades independientes ${ }^{3}$, y la asignación a los sujetos privados de funciones tradicionalmente desempeñadas por las autoridades públicas ${ }^{4}$. Buena prueba de ello es el interés cre-

1 Francisco VELASCO CABALLERO, "El acto administrativo: concepto, clases y contenido", en Eduardo GAMERO CASADO (dir.), Tratado de procedimiento administrativo común y régimen jurídico básico del sector público, Tirant lo Blanch, Valencia, 2017, pp. 1757-1799 (p. 1757).

2 José María BAŃO LEÓN, "derecho al procedimiento en la relación administrativa multipolar (los derechos fundamentales como límite a la renuncia del legislador al control previo de actuaciones)", Revista Española de Derecho Administrativo, núm. 189, 2018.

${ }^{3}$ Luciano PAREJO ALFONSO, La vigilancia y la supervisión administrativas. Un ensayo de su construcción como relación jurídica, Tirant lo Blanch, Valencia, 2016.

4 Dolors CANALS I AMETLLER, "El ejercicio de potestades administrativas por operadores privados en régimen de mercado", en Eduardo GAMERO CASADO (dir.), La potestad administrativa: 
ciente por el concepto de "relación jurídica" como categoría más amplia y flexible que podría permitir explicar mejor algunos de estos desarrollos 5 .

Por otro lado, se ha producido una revalorización de la organización y el procedimiento como elementos clave para explicar cómo opera el derecho administrativo ${ }^{6}$. A ello han contribuido muchos factores, como el abandono del paradigma de la Administración ejecutiva del Estado liberal y el reconocimiento de la importancia que tienen en el Estado social y en el Estado regulador los programas normativos de escasa densidad programadora ${ }^{7}$. En el ámbito europeo, otro factor clave ha sido la fuerte procedimentalización del derecho de la Unión, muy dado a la instrumentación de las normas de procedimiento como estrategia para promover la consecución de objetivos comunes a través de instituciones y ordenamientos jurídicos muy diversos ${ }^{8}$.

Ninguno de estos desarrollos parece haber alterado el "olvido" o "despreocupación" que la dogmática del derecho administrativo ha tenido tradicionalmente con respecto a la categoría del expediente administrativo ${ }^{9}$. Esta afirmación puede parecer contradictoria, dada la tradicional confusión terminológica entre procedimiento y expediente que se da en nuestro derecho y en nuestra doctrina ${ }^{10}$. En efecto, los administrativistas hablamos muchas veces de procedimiento (entendido este como la concatenación de actuaciones que debe llevar a cabo la Administración con carácter previo a la adopción de una decisión vinculante) cuando queremos decir expediente (entendido este como el soporte documental e informativo sobre la base del cual se toma dicha decisión). No se trata de enmendar aquí un uso lingüístico que está muy arraigado y que en la mayor parte de los casos no plantea ningún problema práctico.

concepto y alcance práctico de un criterio clave para la aplicación del Derecho administrativo, Tirant lo Blanch, Valencia, 2021, pp. 320-387; Rafael CABALLERO SÁNCHEZ, "La extensión del derecho administrativo y su proyección contencioso-administrativa”, Teoría y Método: Revista de Derecho Público, núm. 4, 2021, pp. 7-65.

5 Dolores UTRILLA FERNÁNDEZ-BERMEJO, "La relación jurídica en el sistema de derecho administrativo", Revista de Derecho Público: Teoría y Método, núm. 2, 2020, pp. 73-118.

6 Eberhard SCHMIDT-ASSMANN, La teoría general del derecho administrativo como sistema, Marcial Pons, Madrid, 2003, pp. 251-285 y 358-382.

7 Luciano PAREJO ALFONSO, "Organización y procedimiento administrativos", en Luciano PAREJO ALFONSO y Marcos VAQUER CABALLERÍA (dirs.), Estudios sobre el procedimiento administrativo. III Instituciones, Tirant lo Blanch, Valencia, 2020, pp. $27-52$ (p. 35); José María RODRÍGUEZ DE SANTIAGO, La Administración del Estado social, Madrid, Marcial Pons, 2007, p. 97.

8 Xabier ARZOZ SANTISTEBAN, "La autonomía institucional y procedimental de los Estados miembros en la Unión Europea: mito y realidad”, Revista de Administración Pública, núm. 191, 2013, pp. 159-197 (pp. 188-196); Mariolina ELIANTONIO y Elise MUIR, "Concluding Thoughts: Legitimacy, Rationale and Extent of the Incidental Proceduralisation of EU Law", Review of European Administrative Law, núm. 8, 2015, pp. 177-204 (p. 177); Javier BARNES, "Administrative Procedure", en Peter CANE, Herwig C.H. HOFMANN, Eric C. IP y Peter L. LINDSETH (eds.), The Oxford Hadkbook of Comparative Administrative Law, Oxford University Press, Oxford, 2020 (p. 834).

9 Patricia VALCÁRCEL FERNÁNDEZ, "Documentos y archivos electrónicos", en José Luis PINAR MAÑAS, Administración electrónica y ciudadanos, Civitas, Madrid, 2011, p. 617.

10 Marcos VAQUER CABALLERÍA, “¿Para qué sirve el procedimiento administrativo?”, en Luciano PAREJO ALFONSO y Marcos VAQUER CABALLERİA (dirs.), Estudios sobre el procedimiento administrativo. III Instituciones, Tirant lo Blanch, Valencia, 2020, pp. 53-82 (p. 65). 
Sin embargo, esta confusión es reveladora del déficit de elaboración dogmática que afecta al concepto de expediente administrativo ${ }^{11}$.

Este déficit es sorprendente porque la doctrina administrativista contemporánea concibe el procedimiento administrativo como un mecanismo ordenado de obtención de la información sobre la base de la cual se toman las decisiones ${ }^{12}$. No cabe duda de que, como cualquier definición, esta presenta algunas limitaciones, y no faltan quienes han tratado de matizarla o completarla ${ }^{13}$. Sin embargo, parece claro que la generación de información es una de las principales funciones, si no la principal, del procedimiento administrativo. Si esto es así, no deja de ser sorprendente que la dogmática no preste mayor atención a su producto principal: el expediente que recoge toda esa información sobre la base de la cual habrá de tomarse la decisión correspondiente.

Además, se da la circunstancia de que una de las escasas novedades de la reforma de la legislación administrativa de 2015 fue la incorporación a la Ley de Procedimiento Administrativo Común de una definición del expediente administrativo que, hasta entonces, solo figuraba en la legislación de régimen local ${ }^{14}$. La incorporación de esta definición en el art. 70 LPAC no ha servido para corregir la confusión terminológica entre procedimiento y expediente en que incurre la propia ley. Un buen ejemplo de ello es el art. 82 LPAC, que se refiere a la obligación de poner de manifiesto el "procedimiento" al regular el derecho a la vista del expediente que asiste a los interesados en el contexto del trámite de audiencia. A pesar de ello, la incorporación de la definición de expediente administrativo a la legislación sobre procedimiento administrativo común muestra el interés del legislador por una categoría a la que no siempre se le da el protagonismo que merece.

La tesis de este trabajo es que el expediente administrativo merece ocupar un lugar central en la dogmática del derecho administrativo contemporáneo. Para sustentar esta tesis, comenzaré haciendo algunas aclaraciones sobre el concepto mismo de expediente administrativo y sobre la necesidad de ir más allá de una concepción puramente formal o documental del mismo (2). Solo así es posible apreciar en toda su extensión las funciones que desempeńa el expediente administrativo, como pieza clave en el control pero también en la dirección de la acción administrativa formalizada (3). Además, esta comprensión del expediente administrativo puede contribuir a aclarar y enriquecer la teoría de los vicios del procedimiento (4) y la teoría del control de la discrecionalidad administrativa (5).

11 En el mismo sentido Ricardo RIVERO ORTEGA, El expediente administrativo. De los legajos a los soportes electrónicos, 2. ${ }^{\mathrm{a}}$ ed. Cizur Menor, Aranzadi, 2008, p. 33.

12 SCHMIDT-ASSMANN, 2003: 358.

13 VAQUER CABALLERÍA, 2020: 65.

14 Dolors CANALS I AMETLLER, "La actuación de las Administraciones Públicas ante la reciente reforma del procedimiento administrativo común”, Revista Jurídica de la Comunidad de Madrid, núm. 2018, 2018. 


\section{EL CONCEPTO DE EXPEDIENTE ADMINISTRATIVO: CONCEPCIÓN DOCUMENTAL Y MATERIAL}

Este trabajo no puede comenzar sin algunas aclaraciones sobre el significado del concepto de expediente administrativo. Estas aclaraciones son necesarias porque, como ya he señalado, existe una arraigada tendencia a utilizar indistintamente los conceptos de procedimiento y expediente administrativos. A la hora de explicar el significado del concepto de expediente administrativo, es posible adoptar dos perspectivas distintas.

Desde un punto de vista formal, el expediente administrativo es la plasmación documental de los distintos trámites del procedimiento: el repositorio en el que se vuelcan todos los documentos generados a lo largo del mismo ${ }^{15}$. Esta es la perspectiva que adoptan el art. 70.1 LPAC al definir el expediente administrativo como "conjunto ordenado de documentos y actuaciones" y el art. 70.2 LPAC al disponer que "los expedientes administrativos tendrán formato electrónico". También es la perspectiva propia del art. $48 \mathrm{LJCA}$, que regula el requerimiento y remisión del expediente administrativo al inicio del proceso contencioso-administrativo. El origen y naturaleza de los documentos que puede contener el expediente administrativo son muy variados. Esto se debe a la propia flexibilidad del concepto de documento ${ }^{16}$, pero también a la apertura del expediente administrativo a las aportaciones de una gran variedad de actores. El propio órgano instructor puede incorporar documentos al expediente, pero también pueden hacerlo otros órganos administrativos (vía informes), los interesados (vía solicitud, alegaciones o audiencia) e incluso los terceros no interesados (vía información pública).

Sin embargo, el expediente es mucho más que un repositorio documental y comprenderlo es necesario para aprehender la diversidad de funciones que desempeña el expediente en el derecho administrativo contemporáneo. Desde una perspectiva material, el expediente administrativo es la información que contienen todos los documentos que lo componen. Y si la fuente de la que proceden dichos documentos puede ser enormemente variada, el contenido de los mismos puede serlo mucho más. Esto se debe, en primer lugar, a que los documentos pueden y suelen contener información generada por actores distintos de los que los incorporan al expediente. Aunque estos últimos son los que filtran y controlan la información del expediente, pueden plasmar en él información procedente de otras fuentes. Por ejemplo, tanto la Administración como los particulares pueden incorporar testimonios de terceros por cualquiera de las vías mencionadas anteriormente, algo que también puede ocurrir a

15 RIVERO ORTEGA: 2008, 94: "Expediente administrativo es el conjunto de documentos ordenados por la Administración sobre un asunto determinado".

${ }_{16}$ Francisco Javier SANZ LARRUGA, "Gestión documental", en Eduardo GAMERO CASADO (dir.), Tratado de procedimiento administrativo común y régimen jurídico básico del sector público, Tirant lo Blanch, Valencia, 2017, pp. 913-995 (pp. 924 y siguientes). 
través del trámite de prueba ${ }^{17}$. Esta es la vía de entrada al expediente de información producida por técnicos y especialistas o del testimonio de testigos y otros terceros no interesados, a pesar de que en la mayoría de los casos no tienen la consideración de parte en el procedimiento.

En segundo lugar, la naturaleza de la información emanada de esas fuentes puede ser igualmente variada. El procedimiento administrativo es ante todo un procedimiento epistémico cuya finalidad es establecer la verdad de los datos fácticos sobre los que hay que adoptar la decisión ${ }^{18}$. Estos datos fácticos "son" el expediente administrativo en sentido material. Ahora bien, sería probablemente un error pensar que el expediente recoge únicamente datos fácticos, si por tal entendemos proposiciones descriptivas de la realidad. Esta forma de pensar responde al paradigma liberal de la Administración que aplica reglas o programas normativos condicionales mediante la fijación de los hechos y la técnica de la subsunción, pero no refleja bien la complejidad de la Administración contemporánea

En efecto, los programas normativos propios del derecho administrativo contemporáneo revisten a menudo la forma de principios (mandatos de optimización), cuya aplicación requiere de la técnica de la ponderación ${ }^{19}$. Esto exige pensar en el procedimiento administrativo no solo como un mecanismo para la fijación de hechos, sino también como un mecanismo para la identificación de intereses. A su vez esto abre el procedimiento a opiniones o proposiciones valorativas que encajan mal con la noción de datos fácticos ${ }^{20}$. De esta forma, la querencia de la disciplina por el concepto de "hechos" no ayuda a apreciar la diversidad de datos que puede contener el expediente. En cualquier caso, la dicotomía entre proposiciones descriptivas y valorativas no se da de una manera tan nítida en la realidad. Diferenciar unas y otras es precisamente una de las tareas de la Administración, sobre cuyos hombros también recae la tarea de valorar la pertinencia y la fiabilidad de la información recogida en el expediente, como paso previo a la toma de cualquier decisión y lo único que quiero

17 Concepción BARRERO RODRÍGUEZ, La prueba en el procedimiento administrativo, Aranzadi, Cizur Menor, 2003, p. 291; Concepción BARRERO RODRÍGUEZ, "El procedimiento administrativo común en la Ley de 2015: su estructura”, en Luciano PAREJO ALFONSO y Marcos VAQUER CABALLERÍA (dirs.), Estudios sobre el procedimiento administrativo. III Instituciones, Tirant lo Blanch, Valencia, 2020, pp. 165-236 (p. 204).

18 Luis MEDINA ALCOZ, “Los hechos en el derecho administrativo. Una aproximación”, Revista Española de Derecho Administrativo, núm. 177, 2016 (versión electrónica sin paginación); José María RODRÍGUEZ DE SANTIAGO, Metodología del derecho administrativo. Reglas de racionalidad para la adopción y control de la decisión administrativa, Marcial Pons, Madrid, 2016, p. 42.

19 Luis ARROYO JIMÉNEZ, "Ponderación, proporcionalidad y derecho administrativo", Indret: Revista para el Análisis del Derecho, núm. 2, 2009 (p. 4).

20 En este sentido, VAQUER CABALLERÍA, 2020: 66, para quien el procedimiento también contrasta "opiniones y voluntades". En este trabajo, Marcos Vaquer opone estas "opiniones y voluntades" a la "información" en un intento por matizar la concepción del procedimiento como secuencia organizada de obtención y tratamiento de la información de Schmidt-Assman. En mi opinión no existe tal contradicción: estas “opiniones" y "voluntades" son “información” que puede ser relevante para identificar intereses y para ponderar los costes y beneficios potenciales de las decisiones. 
resaltar aquí es la apertura del expediente administrativo a información de cualquier tipo.

Las dos concepciones del expediente administrativo (la formal o documental y la material o sustantiva) son complementarias: reflejan aspectos distintos de la realidad y no se trata de presentar aquí un falso dilema o problema dogmático. Lo que sí es importante destacar es la insuficiencia de la concepción formal o documental para aprehender en toda su extensión las funciones que el expediente administrativo desempeña desde el punto de vista de la dirección y el control de la Administración.

En efecto, pensar en el expediente administrativo en clave exclusivamente documental puede generar la falsa percepción de que su única función es dejar constancia de que la Administración ha seguido el procedimiento legalmente establecido: que se ha escuchado a los interesados, que se han recabado los informes pertinentes, que se ha celebrado el trámite de información pública en los casos en los que este es preceptivo y, además, que todo esto se ha hecho en el orden y dentro de los plazos legalmente establecidos. Esta concepción reduce la función del expediente a una herramienta de control de la legalidad de la acción administrativa y, en concreto, de la legalidad procedimental: como si su principal o única misión fuera dar fe de que se han seguido de manera ritual y puntual los trámites pertinentes. Por el contrario, la concepción material del expediente administrativo (la que pone el foco en el contenido y no en el continente) permite apreciar mejor cuáles son sus funciones.

En los siguientes apartados trataré de identificar estas funciones. Antes de hacerlo, una aclaración adicional: a lo largo de este trabajo, me referiré únicamente al expediente administrativo propio de la toma de decisiones aplicativas (actos administrativos) por oposición a la adopción de normas que innovan el ordenamiento jurídico (reglamentos). Muchas de las consideraciones que se hacen aquí son probablemente aplicables en ese contexto, pero eso es algo que queda fuera del ámbito de este trabajo.

\section{EL EXPEDIENTE ADMINISTRATIVO COMO INSTRUMENTO DE DIRECCIÓN Y CONTROL DE LA ACCIÓN ADMINISTRATIVA}

El expediente administrativo es el reflejo documental del procedimiento y como tal sirve para verificar a posteriori que la Administración ha seguido efectivamente el procedimiento legalmente establecido. Volveré sobre este tipo de control en el siguiente apartado. Antes de hacerlo, es necesario aclarar que, en contra de lo que podría sugerir una concepción estrictamente formal o documental, el expediente administrativo desempeña también otras funciones: por un lado, no es únicamente un instrumento de control sino que también es un instrumento de dirección de la acción administrativa; por otro, su función como instrumento de control no se reduce a la legalidad procedimental sino que también contribuye al control de la legalidad material. A continuación desarrollaré estas dos ideas. 
Empiezo por la primera: el expediente administrativo no puede ser reducido a un instrumento de control de la legalidad de la acción administrativa, porque es también una pieza clave en el engranaje jurídico que dirige la acción de la Administración.

Este engranaje incluye reglas (programas normativos condicionales) y principios (mandatos de optimización), pero también y cada vez más disposiciones organizativas y de procedimiento ${ }^{21}$. La importancia del procedimiento como instrumento de dirección de la acción administrativa en el derecho contemporáneo es un fenómeno ampliamente estudiado. Entre sus causas se suele destacar las dificultades que plantea la dirección de la acción administrativa en contextos de gran complejidad o incertidumbre, como son la regulación económica y la gobernanza del riesgo ${ }^{22}$. En el contexto europeo, estas tendencias se ven reforzadas por la fuerte impronta procedimental del derecho de la Unión ${ }^{23}$.

Desde el punto de vista de este trabajo, lo importante es apreciar cómo opera esa influencia directiva que el procedimiento ejerce sobre la acción administrativa. Ciertamente, las normas sobre procedimiento condicionan cómo se desarrolla la acción administrativa, porque marcan los pasos y los tiempos que esta debe seguir: los "trámites" y el "ritmo" a los que se refería Santamaría de Paredes ${ }^{24}$. A esta idea responde la imagen tradicional del procedimiento como un "cauce" o "camino" a través del cual se desarrolla la acción administrativa ${ }^{25}$.

Sin embargo, la fuerza directiva del procedimiento administrativo se refiere también - y sobre todo- a una idea más profunda: la idea de que la información recabada a lo largo del procedimiento condiciona y modula la decisión final. Las normas de procedimiento determinan la información que debe recopilar la Administración antes de tomar sus decisiones y es esa información (es decir, el expediente en sentido material) la que orienta el sentido y contenido de dichas decisiones. Para que esto ocurra, el derecho administrativo cuenta con varios instrumentos diseńados para asegurar la fuerza directiva del expediente. Me refiero a las normas sobre cómo debe procesarse la información contenida en el expediente: la obligación de tener en cuenta esa información; la obligación de congruencia o de resolver todas las cuestiones suscitadas en el mismo; y, sobre todo, la obligación de motivar sus decisiones a la luz de esa información (es decir, a la luz precisamente del expediente administrativo). Así, la fuerza directiva del procedimiento no radica tanto en la realización ritual de sus trámites como en la influencia racionalizadora que el expediente administrativo ejerce sobre cualquier resolución debidamente motivada. Dicho de otra forma, lo

${ }^{21}$ Javier BARNES, "Sobre el procedimiento administrativo: evolución y perspectivas", en Javier BARNES (ed.), Innovación y reforma en el derecho administrativo, Global Law Press, Sevilla, 2006, p. 271; RODRÍGUEZ DE SANTIAGO, 2016: 20-21.

22 PAREJO ALFONSO, 2020: 41.

${ }_{23}$ Supra, n.8.

${ }^{24}$ Marcos VAQUER CABALLERÍA, "La codificación del procedimiento administrativo en España”, Revista General del Derecho Administrativo, núm. 42, 2016 (sin paginación).

25 VAQUER CABALLERÍA, 2020: 63. 
que dirige no es tanto el procedimiento como el expediente administrativo, entendido en un sentido material.

Esto explica el escaso juego del principio de preclusión en el procedimiento administrativo y, especialmente, en el procedimiento administrativo común: la regulación no se preocupa apenas por el "orden" en el que se realizan las actuaciones procedimentales y de hecho se promueve la realización simultánea de las mismas siempre que esto resulte oportuno ${ }^{26}$. La preclusión opera fundamentalmente en relación con actuaciones procedimentales cuyo fin es permitir que algún órgano o sujeto privado reaccione a la información recabada previamente a través de otro trámite, como ocurre con el trámite de audiencia a los interesados (que debe realizarse una vez terminada la instrucción y, en el caso del procedimiento administrativo sancionador, una vez ha sido elaborada la propuesta de resolución) ${ }^{27}$ o con algunos informes (cuya función es valorar la información del expediente) ${ }^{28}$. A su vez, todo ello explica por qué el orden del expediente no tiene que ser necesariamente cronológico ${ }^{29}$.

Toca ahora abordar la segunda idea que he adelantado antes: la idea de que el expediente opera como un instrumento de control de la legalidad administrativa en su vertiente material (y no solo en la procedimental).

En efecto, el expediente administrativo desempeña una importante función en el control de la congruencia y la racionalidad de la acción administrativa. Desde el punto de vista jurídico administrativo, el principio de congruencia exige que haya una correspondencia entre las cuestiones suscitadas a lo largo del procedimiento administrativo y las que se abordan en la resolución final (lo que equivale a decir entre el contenido del expediente y el acto administrativo correspondiente) ${ }^{30}$. Esta regla encierra en realidad dos exigencias distintas. En su dimensión negativa, el principio de congruencia exige que la Administración se abstenga de abordar o resolver cuestiones no planteadas previamente en el expediente: además de un problema de congruencia, esto sería un problema desde el punto de vista del principio contradictorio, puesto que supondría abordar en la resolución final cuestiones sobre las que los interesados no han tenido ocasión de pronunciarse por ninguna vía ${ }^{31}$. De ahí la exigencia de que la Administración someta a la consideración de los interesados las "cuestiones conexas" sobre las que estos no hayan podido pronunciarse antes, siempre que sea necesario resolver sobre las mismas ${ }^{32}$.

26 Art. 71.2 LPAC.

27 Art. 82 LPAC.

28 Art. 81.2 LPAC (informe del Consejo de Estado en los procedimientos de responsabilidad patrimonial).

29 Oriol MIR PUIGPELAT, Transparencia y procedimiento administrativo. El derecho de acceso al expediente y su conexión con el derecho de acceso a información pública, Civitas, Madrid, 2019, p. 95.

30 Eduardo GARCÍA DE ENTERRÍA y Tomás-Ramón FERNÁNDEZ, Curso de Derecho Administrativo, Vol. II, 14. ${ }^{\mathrm{a}}$ ed. Civitas, Madrid, 2015, p. 509.

31 Ibid.

32 Art. 88.1 LPAC, segundo párrafo. 
En su dimensión positiva, el principio de congruencia exige que la Administración aborde o resuelva todas las cuestiones significativas que emanan del expediente $^{33}$. Esta segunda exigencia está estrechamente entrelazada con la exigencia de motivación entendida en sentido material (esto es, con la obligación que recae sobre la Administración de justificar racionalmente sus decisiones y no simplemente como la obligación formal de presentar algún tipo de explicación en apoyo de las mismas). La combinación de ambas exigencias es una de las principales herramientas con la que cuenta el derecho administrativo para controlar la racionalidad de la acción administrativa, puesto que impide que la Administración deje sin abordar cuestiones espinosas o complicadas de justificar (congruencia) y a la vez exige que justifique racionalmente su decisión a la luz de esas y de cualesquiera otras cuestiones que se hayan suscitado a lo largo del procedimiento (motivación). Así, si no fuera por la exigencia de congruencia, la obligación de motivación perdería gran parte de su fuerza racionalizadora, porque permitiría a la Administración hacer la vista gorda sobre cuestiones complicadas o inoportunas: objeciones planteadas por los interesados, datos contradictorios, etcétera ${ }^{34}$.

En este contexto, el expediente administrativo desempeña una importante función, como instrumento que permite llevar a cabo el control de congruencia y racionalidad de las decisiones administrativas. En efecto, el expediente es el parámetro de control de la congruencia de la decisión administrativa, en la medida en que recoge toda la información que el órgano instructor y el resto de actores que pueden influir sobre el expediente consideran relevante para la toma de la decisión final. El expediente administrativo es también y al mismo tiempo el principal parámetro de control de la racionalidad de dichas decisiones. La motivación sirve para controlar la coherencia interna de las decisiones administrativas y para eliminar o depurar aquellas que incurren en contradicciones. Sin embargo, su principal función, especialmente en el contexto de decisiones complejas, es enjuiciar la coherencia de las decisiones y de las razones aducidas en ellas con la información que se ha recogido a lo largo del procedimiento. Esto explica que en los procedimientos selectivos y de concurrencia competitiva la jurisprudencia no exija que la resolución contenga toda la información relevante para justificar la decisión ${ }^{35}$. En contra de lo que suele afirmar, no es que la motivación pueda encontrarse en el expediente. La motivación está en la resolución pero esta puede ser sucinta si los criterios de valoración son claros y si los datos sobre la base de los cuales se han aplicado están claramente reflejados del expediente.

33 Art. 88.1 LPAC, primer párrafo.

34 Esto explica también la lógica de separar los órganos de instrucción y resolución en procedimientos particularmente sensibles, como los sancionadores (art. 63.1 LPAC). Se trata de que el órgano de resolución decida sin los sesgos que puede haber adquirido a lo largo de la instrucción el órgano encargado de la misma. Pero se trata también de que lo haga constreńido por la información generada a lo largo de la instrucción.

35 Ricardo DE VICENTE DOMINGO, La anulación de los actos administrativos por motivos formales, Tirant lo Blanch, Valencia, 2018, p. 85. 
De todo lo anterior se deduce que el expediente administrativo es una pieza clave para entender cómo opera el derecho administrativo en sus dos dimensiones. El expediente administrativo es, por un lado, un instrumento clave a la hora de dirigir la acción administrativa formalizada. Además, el expediente administrativo es un instrumento clave en el control de la legalidad de la acción administrativa: de la legalidad procedimental pero también y sobre todo de la legalidad material. Esto se debe a que el control de la congruencia y racionalidad de la acción administrativa se hace normalmente a través de un juicio de contraste entre la decisión y el expediente sobre la base del cual ha sido adoptada.

\section{EL EXPEDIENTE ADMINISTRATIVO Y LA TEORÍA DE LOS VICIOS DE PROCEDIMIENTO}

Tal y como he adelantado antes, la función más evidente del expediente administrativo es la de servir de instrumento de control de la legalidad procedimental, dado que recoge todas las actuaciones desarrolladas por la Administración en el curso de un procedimiento, así como los plazos en los que cada una de ellas se ha practicado. Esta es probablemente la función primigenia del expediente administrativo en nuestro derecho: la razón por la que la ley Azcárate y los decretos ministeriales que la desarrollaron ya exigían dejar constancia de los trámites y de los tiempos en que fueron realizados ${ }^{36}$. El expediente administrativo no ha dejado nunca de desempeñar esta función, que sigue siendo útil y necesaria en el derecho administrativo contemporáneo.

Sin embargo, como es bien sabido, el control de la legalidad procedimental en el derecho administrativo contemporáneo dista mucho de ser una tarea mecánica. Este control no consiste en el simple contraste del expediente administrativo con una lista de verificación o checklist. Esto se debe a que la discrecionalidad o indeterminación normativa no solo afecta a las normas materiales sino también a las procedimentales ${ }^{37}$ y a que los procedimientos administrativos nunca están completamente formalizados (una idea sobre la que volveré en el siguiente apartado). Además, el derecho administrativo contemporáneo no ve en el procedimiento un "fin en sí mismo", sino un instrumento al servicio de otros fines del ordenamiento jurídico ${ }^{38}$. Una de las

36 RIVERO ORTEGA, 2008: 72, que habla de la "consagración de un principio de formación de expedientes".

37 Eva DESDENTADO DAROCA, "Discrecionalidad administrativa y procedimiento administrativo", en Luciano PAREJO ALFONSO y Marcos VAQUER CABALLERÍA (dirs.), Estudios sobre el procedimiento administrativo. III. Instituciones, Tirant lo Blanch, Valencia, 2020, pp. 83-122 (p. 85). Aunque su tesis es, justamente, que la legislación sobre procedimiento reduce el margen de discrecionalidad mediante conceptos jurídicos indeterminados como el estándar del procedimiento debido, que analizo más adelante.

38 Gabriel DOMÉNECH PASCUAL, "Las irregularidades no invalidantes desde una perspectiva económica", El alcance de la invalidez de la actuación administrativa: Actas del XII Congreso de la Asociación Española de Profesores de Derecho Administrativo, INAP, Madrid, 2017, pp. 151-170 (p. 158). 
principales consecuencias que tiene la superación de concepciones ritualistas del procedimiento administrativo es la aceptación de que no todas sus infracciones tienen las mismas consecuencias jurídicas. Es precisamente en el contexto de la determinación de las consecuencias jurídicas que tienen los vicios de procedimiento donde el expediente administrativo desempeña otra función que a veces pasa desapercibida. Reconocer dicha función puede contribuir a mejorar la teoría de los vicios del procedimiento y de sus efectos invalidantes.

Para introducir esta idea, conviene repasar rápidamente la evolución que ha experimentado nuestro derecho en torno a esta cuestión ${ }^{39}$. Los orígenes del problema se remontan a la vieja Ley de Santamaría de Paredes de 1888, primera ley sobre la jurisdicción contencioso-administrativa en España. Esta ley excluía del ámbito de la jurisdicción contencioso-administrativa las decisiones discrecionales, lo cual impedía la revisión jurisdiccional de una parte muy significativa de la acción administrativa. Para paliar este problema, los tribunales del orden contencioso-administrativo desarrollaron la llamada "doctrina de los vicios de orden público", a la que TomásRamón Fernández daría nombre y sentido años después ${ }^{40}$. Al considerar los vicios de procedimiento como vicios de orden público que los tribunales podían revisar de oficio y con carácter previo a cualquier otro motivo de impugnación, esta doctrina abrió una vía que permitía un mínimo control de legalidad sobre la discrecionalidad administrativa. Sin embargo, esto se logró a costa de adoptar una concepción muy ritualista de la legalidad procedimental: precisamente porque en muchos casos este era el único estándar de control que podían utilizar, los tribunales tendían a aplicarlo con enorme rigor y formalismo. Además, producía algunos resultados perversos, como la reticencia de los tribunales a entrar al fondo del asunto siempre que había un problema de procedimiento, incluso en asuntos en los que se revisaban decisiones regladas ${ }^{41}$.

La situación cambió a raíz de las profundas reformas de la legislación administrativa que se produjeron en la década de los años cincuenta. En primer lugar, la Ley de procedimiento administrativo de 1958 dejó claro que no todos los vicios de procedimiento comprometían la validez de la resolución final, introduciendo la distinción, todavía actual, entre los vicios de procedimiento que son causa de nulidad o anulabilidad y los que constituyen meras "irregularidades no invalidantes". En segundo lugar, la Ley de la jurisdicción contencioso-administrativa de 1956 abrió

39 Para un análisis reciente y más detallado: Antonio DESCALZO GONZÁLEZ, "La forma en el procedimiento administrativo", en Luciano PAREJO ALFONSO y Marcos VAQUER CABALLERÍA (dirs.), Estudios sobre el procedimiento administrativo. III. Instituciones, Tirant lo Blanch, Valencia, 2020, pp. 237-306.

40 Tomás-Ramón FERNÁNDEZ RODRÍGUEZ, "La doctrina de los vicios de orden público en el contencioso-administrativo: orígenes y evolución”, Revista de Administración Pública, núm. 57, 1968, pp. 223-277; Tomás-Ramón FERNÁNDEZ RODRÍGUEZ, "Los vicios de orden público y la teoría de las nulidades en el derecho administrativo", Revista de Administración Pública, núm. 58, 1969, pp. 49126.

41 FERNÁNDEZ RODRÍGUEZ, 1969: 123. 
las puertas de dicha jurisdicción a las decisiones discrecionales de la Administración. Estos cambios trajeron consigo un abandono progresivo de la doctrina de los vicios de orden de público.

Como si de una reacción pendular se tratara, la superación de la doctrina de los vicios de orden público trajo consigo una cierta "hipertrofia de las irregularidades no invalidantes" ${ }^{42}$. Si el problema al amparo de dicha doctrina era el carácter invalidante que tenían todas las infracciones de procedimiento, por muy intrascendentes que fueran, el nuevo régimen jurídico planteaba un riesgo de signo opuesto: el de interpretar de manera excesivamente restrictiva los vicios de procedimiento que afectan a la resolución final, dejando sin sanción la mayoría de infracciones procedimentales cometidas por la Administración. Más allá de las consecuencias perversas que esto puede tener desde el punto de vista de los interesados, el peligro estaba en el impacto que la extensión de la doctrina de las irregularidades no invalidantes podía tener sobre la fuerza directiva de las normas de procedimiento (esto es, sobre los incentivos que tiene la Administración para respetar normas carentes, en la práctica, de toda sanción).

La cuestión es complicada y no se trata de tratar de resolver aquí un problema que se deriva, como todos los grandes problemas del derecho administrativo, de la tensión entre la eficacia de la acción administrativa y las exigencias del principio de legalidad y del Estado de derecho. De lo que se trata es de observar que el abandono de la doctrina de los vicios de orden público y el reconocimiento legal de que no todos los vicios de procedimiento son causa de invalidez de la resolución administrativa correspondiente hicieron necesario teorizar acerca de los criterios que debían guiar a los aplicadores del derecho a la hora de abordar esta cuestión: a la hora de decidir qué infracciones procedimentales son causa de nulidad o anulabilidad y cuáles son meras irregularidades no invalidantes. Desde un punto de vista doctrinal, la cuestión que reviste mayor complejidad es la que se refiere a la distinción entre las infracciones procedimentales que son causa de anulabilidad y las meras irregularidades no invalidantes. Me centraré por tanto en esta cuestión y no en la delimitación de los supuestos de nulidad y anulabilidad, un "dilema [...] condenado a su irresolubilidad" 43 .

La disposición de referencia sobre este punto es, evidentemente, el art. 48.2 LPAC, según el cual "el defecto de forma solo determinará la anulabilidad cuando el acto carezca de los requisitos formales indispensables para alcanzar su fin o dé lugar a la indefensión de los interesados".

La expresión "requisitos formales" engloba los requisitos formales en sentido estricto (requisitos que tienen que ver con la exteriorización del acto) pero también los procedimentales. Aunque hay argumentos textuales, sistemáticos y finalistas para

42 César CIERCO SEIRA, La participación de los interesados en el procedimiento administrativo, Publicaciones del Real Colegio de España, Bolonia, 2002, p. 41.

43 Ángel M. MORENO MOLINA, "Los vicios del procedimiento administrativo y su control judicial”, en Luciano PAREJO ALFONSO y Marcos VAQUER CABALLERÍA (dirs.), Estudios sobre el procedimiento administrativo. III. Instituciones, Tirant lo Blanch, Valencia, 2020, pp. 307-399 (p. 317). 
sostener una interpretación distinta ${ }^{44}$, lo cierto es que los antecedentes legislativos y la comprensión generalizada de este precepto tanto por la jurisprudencia como por la doctrina avalan esta interpretación ${ }^{45}$. Por tanto, no tendría sentido tratar de impugnarla aquí. La cuestión entonces es precisar el significado de la fórmula "indispensables para alcanzar su fin", es decir, el criterio de la indispensabilidad o necesidad ${ }^{46}$.

La interpretación primigenia de esta fórmula se apoyaba sobre la premisa de que la finalidad de las normas de procedimiento es asegurar la legalidad material de la decisión final, al movilizar o generar la información necesaria para subsumir el supuesto de hecho en la norma. De ahí que esta interpretación abogara por sancionar con invalidez aquellos vicios que comprometen la legalidad material de la decisión final, al privar al órgano decisor de un dato o de una información sin la cual no podía aplicar correctamente dicha norma ${ }^{47}$.

Esta interpretación se vio rápidamente superada por la observación de que la finalidad de las normas de procedimiento no se limita a asegurar la legalidad de las decisiones administrativas sino también su oportunidad. Esta funcionalidad es especialmente importante en el caso de decisiones discrecionales, donde no existe una única solución correcta o legal y donde el procedimiento sirve precisamente para instruir a la Administración sobre las distintas opciones que tiene y sobre cuál de ellas es la más conveniente. Aplicar de manera automática la interpretación anterior a este tipo de situaciones conduce a resultados insatisfactorios, porque un vicio procedimental puede no afectar a la legalidad de la decisión final (si esta se encuentra entre las legalmente posibles) pero sí privar a la Administración de la posibilidad de valorar algunas de las opciones posibles. De ahí la ampliación de los vicios de procedimiento con carácter invalidante a aquellos que impiden valorar alguna alternativa.

La constatación de este tipo de limitaciones generó una corriente doctrinal de corte más funcional, que aboga por analizar la función de los concretos trámites procedimentales omitidos o incorrectamente realizados en cada caso. Margarita Beladíez Rojo es la principal exponente de esta corriente. En su trabajo sobre la validez y eficacia de los actos administrativos, propone una teoría para explicar las razones por las que el ordenamiento jurídico deja sin sanción algunas infracciones procedimentales, pero también una metodología específica para decidir caso por caso las consecuencias que han de tener este tipo de infracciones. Su tesis es que hay que preguntarse por el fin que perseguía el trámite que ha sido omitido o incorrectamente realizado y analizar si ese fin ha podido ser cumplido por otra vía ${ }^{48}$. Aunque los esfuerzos por perfilar

44 Ibid., 317.

45 DE VICENTE DOMINGO, 2018: 59-61.

46 Aunque MORENO MOLINA, 2020: 340 sostiene que ese criterio se aplica solo a los vicios de forma en sentido estricto y que los vicios de procedimiento se rigen por la cláusula de la indefensión.

47 Javier GARCÍA LUENGO, Las infracciones formales como causa de invalidez del acto administrativo. Un estudio sobre el artículo 48.2 de la Ley 39/2015, Iustel, Madrid, 2016, p. 109.

48 Margarita BELADÍEZ ROJO, Validez y eficacia de los actos administrativos, Marcial Pons, Madrid, 1994. 
la teoría de los vicios de procedimiento no han cesado, este enfoque funcional ha sido muy influyente y ha inspirado las propuestas de muchos autores posteriores ${ }^{49}$.

Todas estas teorías comparten un enfoque funcional que aboga por analizar casuísticamente las consecuencias prácticas que tienen los vicios de procedimiento antes de determinar sus consecuencias jurídicas. A la postre, lo que esto implica es que el contenido del expediente administrativo es lo que debe determinar qué sanción merece cada infracción de procedimiento. Afirmar que un vicio solo debe ser causa de invalidez de la resolución final cuando el trámite o la garantía no cumple su fin es tanto como afirmar que solo deben tener fuerza invalidante los vicios que hayan afectado materialmente al contenido del expediente. Si la información que habría proporcionado ese concreto trámite (o la realización correcta del mismo) ya figura en el expediente, entonces no hay ninguna razón para reconocerle ninguna trascendencia. Poner el foco sobre el expediente es una opción más lógica que ponerlo sobre la decisión final, precisamente porque el contenido de esta última está mediado por un juicio valorativo y volitivo que casi nunca es matemático. Más que preguntarse por el impacto de un vicio sobre la decisión final, lo lógico es preguntarse por su impacto sobre el expediente administrativo en sentido material.

Esta postura tiene además la ventaja de que también sirve para aclarar el significado del segundo criterio que determina el carácter invalidante de los vicios de procedimiento: la generación de indefensión para los interesados. La jurisprudencia y la doctrina rechazan unánimemente una interpretación formal del concepto de indefensión, que podría privar de efecto útil al precepto: si cualquier vicio procedimental generara indefensión, entonces el art. 43.2 LPAC en su conjunto carecería de toda razón de ser. Con apoyo en la jurisprudencia constitucional, la interpretación casi unánime de este precepto es que es solo son causa de invalidez los vicios que generan indefensión material, es decir, los vicios que privan al interesado de una oportunidad concreta de defenderse ${ }^{50}$. Para aplicar esta doctrina, los tribunales suelen exigir que los interesados señalen con precisión de qué manera un vicio les ha afectado: no haber tenido acceso al expediente o a partes de él puede haberles privado de la posibilidad de rebatir alguna idea o dato vertidos en el expediente; no haber tenido ocasión de aportar algún documento puede haberles privado de la posibilidad de suministrar a la Administración algún dato relevante; el rechazo a la práctica de alguna prueba propuesta por ellos puede haberles privado de la posibilidad de poner en duda algún dato del expediente.

Estos ejemplos muestran, de nuevo, la centralidad del expediente para administrar esta regla. Esto se debe a que, a la postre, los derechos de información y participación que los interesados tienen en el marco del procedimiento administrativo son derechos a influir sobre el contenido material del expediente administrativo (con la

49 Por ej., Juli PONCE SOLÉ, Deber de buena administración y derecho al procedimiento administrativo debido. Las bases constitucionales del procedimiento administrativo y del ejercicio de la discrecionalidad, Lex Nova, Valladolid, 2000. Más recientemente, DE VICENTE DOMINGO (2018): 30.

50 MORENO MOLINA, 2020: 340-341. 
influencia indirecta que esto implica sobre la decisión final, por efecto de los principios de congruencia y motivación). Dicho de otra forma, el valor de garantía o protección que tienen los derechos de acceso al expediente y a formular alegaciones (tanto a lo largo del procedimiento como en el trámite específico de audiencia) radica precisamente en el poder de influencia sobre el contenido del expediente que atribuyen a los interesados: el poder de criticar, contradecir o completar la información del expediente con la información que mejor sirva a sus propios intereses. De nuevo, la clave está en la información y no en los rituales: buena prueba de ello es que la propia LPAC excluye la necesidad de celebrar un trámite específico de audiencia al término de la instrucción en aquellos casos en los que no figura en el expediente ningún dato adicional a los aportados por el propio interesado ${ }^{51}$.

Evidentemente, nada de esto excluye que, en algunos casos, el legislador o los aplicadores del derecho sancionen algunas infracciones procedimentales con independencia de su impacto sobre el expediente administrativo. El hecho de que el valor de garantía o protección de los derechos de información y participación radique en la capacidad de influencia sobre el expediente que proporcionan a los interesados no significa que no puedan estar al servicio de otros fines. Esto es algo que la teoría de los vicios de procedimiento resuelve por otra vía, al reconocer como causa de nulidad algunas infracciones (como la omisión o realización defectiva del trámite de audiencia en los procedimientos sancionadores). Precisamente porque el valor atribuido a esas garantías no es instrumental, la sanción que el ordenamiento jurídico anuda a su infracción no depende de su impacto sobre el expediente ${ }^{52}$.

De esta forma, la función del expediente administrativo en el control de la legalidad procedimental no se limita a servir de instrumento para la detección de los errores de procedimiento cometidos por la Administración. Su principal función es orientar la determinación de las consecuencias que deben tener esos errores, en función de su impacto efectivo sobre la información contenida en el expediente. Esta comprensión de los errores de procedimiento y del expediente puede contribuir a enriquecer la teoría de los vicios de procedimiento.

\section{EL EXPEDIENTE ADMINISTRATIVO Y LA TEORÍA DEL CONTROL DE LA DISCRECIONALIDAD}

El análisis desplegado hasta ahora ha puesto de manifiesto que el expediente administrativo es una pieza clave en el control de la legalidad de la acción administrativa, tanto en su dimensión procedimental como material. En el ámbito procedi-

51 Art. 82.4 LPAC.

52 Sobre la distinción entre las garantías procedimentales cuyo fundamento es "esencialista" o "instrumental", en el contexto del derecho de la Unión: Eric BARBIER DE LA SERRE, "Procedural Justice in the European Community Case-law concerning the Rights of the Defence: Essentialist and Instrumental Trends", European Public Law, núm. 12, 2006, pp. 225-250. 
mental, el expediente administrativo sirve como instrumento para la detección de las infracciones procedimentales pero también, y sobre todo, para la determinación de sus consecuencias. En el ámbito material, el expediente administrativo opera como parámetro de referencia para valorar la congruencia y racionalidad de las decisiones administrativas. Tal y como he explicado antes, esta valoración consiste fundamentalmente en un juicio de contraste entre la motivación de la decisión administrativa y la información contenida en el expediente.

Sin embargo, el desarrollo teórico y jurisprudencial del estándar del "procedimiento debido" asigna al expediente una función adicional, que también merece ser explorada. El protagonismo que ha adquirido este estándar en el derecho administrativo contemporáneo tiene mucho que ver con la influencia del derecho de la Unión y del deber de buena administración.

La noción de "buena administración" que maneja el derecho de la Unión encierra en realidad principios, deberes y derechos muy distintos ${ }^{53}$. Uno de los más importantes es el llamado "deber de diligencia e investigación imparcial", que tiene dos componentes principales: el componente "fáctico", en virtud del cual las instituciones de la Unión están obligadas a tomar sus decisiones sobre la base de toda la información relevante; y el componente "cognitivo", en virtud del cual las instituciones de la Unión deben tener en cuenta toda esa información a la hora de tomar sus decisiones ${ }^{54}$. Ambos componentes sirven para revisar la base informativa y la racionalidad de la acción administrativa de las instituciones europeas, especialmente en contextos de incertidumbre y complejidad técnica. Aunque no aparece expresamente recogido en los tratados ni en la Carta de derechos Fundamentales, el Tribunal de Justicia considera que el deber de diligencia es un principio general del derecho de la Unión ${ }^{55}$. De ahí que sea aplicable a toda la acción formalizada de la Unión (incluyendo sus actos legislativos y regulatorios, además de sus decisiones administrativas) ${ }^{56}$. De ahí también que vincule a las autoridades nacionales cuando actúan dentro del ámbito de aplicación del derecho de la Unión ${ }^{57}$.

El desarrollo de este deber a nivel europeo ha ejercido una notable influencia sobre la doctrina y la jurisprudencia espańolas. El mejor exponente de esta influencia es el conocido trabajo de Juli Ponce Solé sobre el deber de buena administración y el

53 H. Peter NEHL, "Good administration as procedural right and/or general principle?", en Herwig C.H. HOFMANN y Alexander TÜRK (eds.), Legal challenges in EU administrative law: towards an integrated administration, Edward Elgar, Cheltenham, 2009, pp. 322-351 (p. 322).

${ }^{54}$ Herwig C.H. HOFMANN, "The Duty of Care in EU Public Law - A Principle Between Discretion and Proportionality", Review of European Administrative Law, núm. 13, 2020, pp. 87-112 (pp. 98-102).

55 Por ej., STJUE (Gran Sala) de 4 de abril de 2017, Defensor del Pueblo c. Claire Staelen, ECLI: EU:C:2017:256, apdo. 34.

${ }^{56}$ Por ej., STJUE (Sala segunda) de 15 de octubre de 2009, Enviro Tech (Europe) c Bélgica, ECLI:EU:C:2009:635, apdo. 62 y STJUE EU:C:2010:32 (Gran Sala) de 8 de junio de 2010, Vodafone, ECLI:EU:C:2010:321, apdo. 55.

57 HOFMANN, 2020: 93. 
derecho al procedimiento debido en España. Para este autor, el deber de buena administración puede ser entendido como "el deber jurídico de situarse en la mejor de las situaciones posibles antes de ejercer la función administrativa, ponderando todos los factores de la decisión" ${ }^{58}$. Su tesis es que este deber está consagrado constitucionalmente, porque se deduce de los arts. 9.3, 31.2 y $103.1 \mathrm{CE}^{59}$. Una de sus consecuencias es, precisamente, el deber de seguimiento del procedimiento debido que recae sobre la Administración y que entrańa un "deber de investigación y ponderación cuidadosa de los elementos fácticos y de los intereses" envueltos en cada caso ${ }^{60}$.

Si esta tesis es correcta, entonces el estándar del procedimiento debido consta de los dos mismos componentes que el deber de diligencia de la jurisprudencia europea: el componente fáctico que obliga a la Administración a situarse en la mejor de las situaciones posibles y a llevar a cabo una investigación apta para destapar todas las circunstancias relevantes de cada asunto; el componente cognitivo que obliga a la Administración a tener en cuenta todas esas circunstancias a la hora de tomar la decisión final. Esto último se controla fundamentalmente a través del escrutinio de la motivación de las decisiones administrativas y de su contraste de congruencia y racionalidad con el expediente administrativo. Dado que ya he abordado esto al comienzo de este trabajo, me centraré aquí en su otra dimensión: la que se refiere al estándar de diligencia que debe guiar a la Administración en la instrucción de los procedimientos administrativos.

$\mathrm{Al}$ margen de sus posibles raíces constitucionales, el fundamento normativo más evidente de este deber de diligencia se encuentra en el art. 75.1 LPAC, según el cual: "Los actos de instrucción necesarios para la determinación, conocimiento y comprobación de los hechos en virtud de los cuales deba pronunciarse la resolución, se realizarán de oficio y a través de medios electrónicos, por el órgano que tramite el procedimiento [...]". La estructura y la fórmula impersonal que emplea este precepto ("se realizarán") pueden hacer que su verdadero significado pase desapercibido.

Ciertamente, este precepto reitera el principio de oficialidad o investigación de oficio consagrado con carácter general por el art. 71.1 LPAC, proyectándolo sobre los actos de instrucción. Este principio configura el procedimiento administrativo en clave inquisitorial, atribuyendo a la Administración la responsabilidad de llevar la iniciativa y de impulsar todos sus trámites. Este principio tiene carácter "estructurante" porque su ámbito de aplicación no se limita a los procedimientos iniciados de oficio ${ }^{61}$. Su ámbito de aplicación también incluye los procedimientos iniciados

58 PONCE SOLE, 2000: 154. En el mismo sentido, Juli PONCE SOLÉ, La lucha por el buen gobierno y el derecho a una buena administracion mediante el estándar jurídico de diligencia debida, Cátedra de Democracia y Derechos Humanos (Universidad de Alcalá y Defensor del Pueblo), Alcalá de Henares, 2019, p. 33, donde afirma que el deber de buena administración "supone la necesidad de análisis y la toma en consideración diligente y con el debido cuidado de los hechos e intereses relevantes en cada toma de decisión".

59 PONCE SOLE, 2000: 154.

60 Ibid.: 262.

${ }^{61}$ RODRÍGUEZ DE SANTIAGO, 2016: 43. 
a solicitud del interesado, si bien en estos casos solo opera cuando el interesado ha presentado una solicitud mínimamente informada. Buena prueba de la operación de este principio en este tipo de contextos es la posibilidad de subsanación y mejora que el art. 68 LPAC obliga o habilita a brindar a los interesados, según los casos.

Sin embargo, el verdadero centro de gravedad del art. 75.1 LPAC está en el estándar de la necesidad, porque su principal función es imponer sobre la Administración el deber de llevar a cabo los actos de instrucción que sean "necesarios" para obtener la información necesaria para decidir ${ }^{62}$. Este estándar se manifiesta en muchas otras disposiciones de la LPAC. Así, el art. 77.2 LPAC exige la celebración de un trámite específico de prueba "cuando la naturaleza del procedimiento lo exija". En el mismo sentido, el art. 77.3 LPAC faculta al instructor a rechazar pruebas propuestas "cuando sean manifiestamente improcedentes o innecesarias". Por su parte, el art. 78.1 LPAC exige la solicitud de todos aquellos informes que sean preceptivos según la legislación vigente, pero también "los que se juzguen necesarios para resolver". Finalmente, el art. 83 LPAC vincula la celebración del trámite de información pública a que la "naturaleza" del procedimiento "lo requiera".

Es posible ver en todos estos preceptos una manifestación del deber de diligencia consagrado en el art. 75 LPAC, verdadero eje vertebrador de la regulación del procedimiento de adopción de las decisiones administrativas formalizadas. Todos ellos utilizan conceptos jurídicos indeterminados para expresar el estándar de diligencia que debe guiar a la Administración, lo cual no es casual: responde a la idea de que las necesidades informativas de la Administración no son uniformes, sino que son una función del tipo de decisión que está en juego en cada caso.

El deber de diligencia ha sido también reconocido por la jurisprudencia como un instrumento que permite valorar la suficiencia de la base informativa sobre la cual se toma una decisión. Por ejemplo, en un asunto reciente sobre subvenciones, el Tribunal Supremo lo definió en los siguientes términos:

\footnotetext{
"En lo que concierne a la regularidad del procedimiento subvencional, procede significar que el derecho al procedimiento administrativo debido, que es corolario del deber de buena administración, garantiza que las decisiones administrativas en materia subvencional se adopten de forma motivada y congruente con el iter procedimental, sin incurrir en desviación del procedimiento, en la medida que se requiere que no haya discordancias de carácter sustancial entre los datos fácticos relevantes, la fundamentación jurídica obrante en el expediente y el contenido de la decisión administrativa." ${ }^{63}$
}

Esta formulación es interesante porque permite apreciar cómo cambia la función del expediente administrativo en el marco del control de la legalidad de la acción administrativa cuando el estándar utilizado es el del procedimiento debido. El juicio de contraste no se produce aquí exclusivamente entre el "expediente" y el "contenido de la decisión administrativa", como ocurre cuando se enjuicia la congruencia y racionalidad de la acción administrativa. En la ecuación interviene un tercer factor:

62 PONCE SOLÉ, 2000: 199; GARCÍA DE ENTERRÍA y FERNÁNDEZ, 2015: 492.

63 STS (sala 3. ${ }^{\text {a) }}$ de 14 de abril de 2021 (ECLI:ES:TS:2021:1387). 
"los datos fácticos relevantes". Este criterio supone un cambio de enfoque con respecto a los anteriores, puesto que el expediente deja de ser un mero instrumento o parámetro de control, para convertirse en el objeto mismo de dicho escrutinio. Al fin y al cabo, enjuiciar la suficiencia de la información sobre la base de la cual se toman las decisiones no consiste en otra cosa que en verificar si el expediente contiene toda la información que la Administración debía valorar. Así, el juicio de contraste no se produce entre la decisión y el expediente, sino entre el expediente y el universo de datos o circunstancias potencialmente relevantes para la toma de la decisión final.

Por supuesto, el procedimiento debido no es una obligación absoluta que exija contar en todo caso con la mayor información posible. En primer lugar, se trata de una obligación "de medios" o "de diligencia" y no "de resultado" "64. Esto quiere decir que lo que se espera de la Administración es que ejerza un deber de diligencia razonable a la vista de las circunstancias. Determinar lo que es exigible en cada caso pasa por evaluar el coste y beneficio esperado de una mayor o menor inversión instructora: ${ }^{65}$ "No es posible — ni compatible con la eficacia de la actuación administrativa- pretender decidir con un grado de seguridad absoluta" ${ }^{66}$. También limitan el alcance de este deber las disposiciones temporales que recorren las normas de procedimiento: la fijación de plazos máximos para resolver persigue entre otras cosas acotar el esfuerzo instructor que se puede esperar de la Administración en cada caso. Finalmente, también hay que señalar aquí el papel que desempeñan los estándares de manejo de la información que contienen las normas materiales y que señalan el grado de certeza necesario para poder tomar una decisión ${ }^{67}$.

La afirmación de que este tipo de control se proyecta sobre el expediente y no sobre el procedimiento puede parecer un mero juego de palabras. Si el objeto de las normas de procedimiento es dirigir la formación del expediente, entonces verificar la suficiencia del expediente exige verificar la regularidad del procedimiento que lo ha producido: que los interesados han podido consultar el expediente y que sus alegaciones constan en el mismo; que se han solicitado e incorporado al expediente todos los informes preceptivos; que en el expediente figuran las aportaciones realizadas por los terceros no interesados en los casos en que fuera preceptivo realizar un trámite de información pública. Desde luego, valorar la suficiencia del expediente pasa necesariamente por comprobar estos extremos. Sin embargo, el tipo de control que se ejerce sobre el expediente no siempre puede reducirse a un ejercicio mecánico de verificación del cumplimiento de las normas de procedimiento. De ahí la utilidad de conceptualizarlo como un control de suficiencia que se ejerce sobre el expediente: no es tanto un juego de palabras, como una precisión terminológica que puede ayudar a comprender mejor cómo opera el control de la discrecionalidad.

64 PONCE SOLÉ, 2000: 200 y 439.

65 Por analogía con la "inversión metodológica" a la que se refiere RODRÍGUEZ DE SANTIAGO, 2016: 17 .

66 Ibid.: 44.

${ }^{67}$ MEDINA ALCOZ, 2016 (versión electrónica sin paginación). 
Esto se debe a que el conjunto de circunstancias que deben ser tenidas en cuenta para adoptar una decisión no es algo que venga determinado por las normas de procedimiento. Las normas de procedimiento estructuran el proceso de búsqueda de información, pero son las normas sustantivas o materiales sobre la base de las cuales actúa la Administración las que determinan qué circunstancias deben valorarse en cada caso. Esta afirmación exige dos aclaraciones. En primer lugar, la determinación de estas circunstancias puede ser más o menos precisa, en función de dónde se sitúen esas normas en el espectro que va desde las reglas condicionales puras hasta los principios más abstractos. Esto no quita para que sean esas reglas o principios (y no las reglas de procedimiento) las que determinan, con un margen variable de abstracción y precisión, las circunstancias a tener en cuenta.

En segundo lugar, el derecho también dirige a la Administración a través de sus reglas de organización y procedimiento. La procedimentalización es una de las señas de identidad del derecho administrativo contemporáneo y su razón de ser radica, como ya he explicado, en la fuerza directiva que se le confía a la información (y, por tanto, al expediente). Sin embargo, las normas de procedimiento no operan nunca en el vacío. Primero, porque la diferencia entre los distintos tipos de programación normativa es de grado y no de cualidad ${ }^{68}$. Por mucho protagonismo que tengan las disposiciones procedimentales en un determinado sector normativo, estas siempre van acompañadas de algún tipo de programación material, por muy general o abstracta que sea. Segundo, porque la actuación de la Administración siempre está sometida a algunos principios transversales, incluidos los que emanan de la vertiente objetiva de los derechos fundamentales y del resto de principios y valores consagrados en la Constitución y en el resto del ordenamiento jurídico.

En principio, las normas de procedimiento deberían estar diseñadas para facilitar la formación de un expediente completo, en el que figuren todas las circunstancias que la Administración debe valorar para tomar cada decisión. Las distintas cláusulas generales sobre procedimiento debido que contiene la LPAC responden precisamente a esta idea, puesto que condicionan la actividad instructora requerida de la Administración a las necesidades de cada caso. Sin embargo, abundan en nuestro derecho los procedimientos formalizados, que son aquellos en los que una norma de rango legal o reglamentario concreta el orden y los trámites que deben seguirse para adoptar determinadas decisiones ${ }^{69}$. Esto exige reflexionar sobre la relación entre el principio de oficialidad y el estándar general de procedimiento debido, por un lado, y las normas de formalización de los procedimientos, por otro. Para abordar esta

${ }^{68}$ José María RODRÍGUEZ DE SANTIAGO, La ponderación de bienes e intereses en el Derecho administrativo, Marcial Pons, Madrid, 2000, p. 11.

69 Francisco GONZÁLEZ NAVARRO, "Procedimiento administrativo común, procedimientos triangulares y procedimientos complejos", Revista de estudios de la vida local, núm. 211, 1981, pp. 409454 (p. 415). En el mismo sentido, Diego VERA JURADO, "Cuestiones generales del procedimiento administrativo", en Eduardo GAMERO CASADO (dir.), Tratado de Procedimiento Administrativo Común y Régimen Jurídico Básico del Sector Público, Tirant lo Blanch, Valencia, 2017, pp. 1273-1309 (p. 1284). 
cuestión, puede ser útil observar que la formalización de los procedimientos plantea potencialmente dos problemas distintos.

El primer problema es que la aplicación rigurosa de las normas de formalización de los procedimientos puede resultar en la realización de actuaciones innecesarias o reiterativas desde el punto de vista del contenido del expediente. En algunos casos, este desajuste es estructural, en el sentido de que es el diseño mismo del procedimiento el que prevé actuaciones que son siempre o casi siempre innecesarias. Esta es la principal preocupación de la literatura sobre simplificación de los procedimientos y de las políticas orientadas a ese fin ${ }^{70}$. En otros casos, el problema es coyuntural y está vinculado a las circunstancias concretas del caso. En cierto modo, la doctrina de las irregularidades no invalidantes analizadas en el apartado anterior permite mitigar este problema: mitiga el riesgo de formalización excesiva, al privar de sanción la omisión de actuaciones innecesarias. Si una norma desprovista de sanción no es una norma imperativa, lo que viene a hacer esta doctrina es privar de carácter imperativo a muchas normas de formalización de los procedimientos ${ }^{71}$.

En cualquier caso, el problema que quiero destacar aquí es el contrario: el riesgo de que la aplicación de las normas de formalización de los procedimientos no sea suficiente para que el expediente recoja toda la información relevante. La respuesta del derecho a este problema radica precisamente en el juego del principio de oficialidad y del estándar del procedimiento debido, que obligan a la Administración a "mirar" más allá de las normas de formalización de los procedimientos y a asegurarse de que sus decisiones cuentan siempre con la base informativa "necesaria". La manifestación más clara de esta idea es probablemente el art. 87 LPAC, que faculta al órgano competente para resolver para volver a abrir la instrucción y ordenar la realización de las "actuaciones complementarias indispensables para resolver el procedimiento". Oficialidad y procedimiento debido operan así como una cláusula de cierre de las normas de procedimiento: ex ante, esta cláusula obliga a la Administración a asegurarse de que cuenta con toda la información necesaria para resolver; ex post, esta cláusula implica que uno de los parámetros básicos para enjuiciar la legalidad de la acción administrativa es la suficiencia del expediente (es decir, la verificación de que refleja todas las circunstancias que debían ser valoradas por la Administración).

Evidentemente, este tipo de control está muy ligado al control de la discrecionalidad y de la ponderación. Aunque no hay ninguna razón de principio para restringir su aplicación a este tipo de situaciones, en la práctica es en contextos de indeterminación normativa y complejidad donde este tipo de control está llamado a tener un especial protagonismo. La literatura sobre este tema ha identificado tres grandes formas de control de la discrecionalidad y la ponderación: un primer tipo control marginal basado en la arbitrariedad (o "razonabilidad en el resultado"), más propio

70 Por ej., Luis MÍGUEZ MACHO, Marcos ALMEIDA CERREDA y Diana SANTIAGO IGLESIAS (coord.), La simplificación de los procedimientos administrativos, Actas del IX Congreso de la AEPDA, 2014.

71 BELADÍEZ ROJO, 1994: 158. 
del pasado ${ }^{72}$; un segundo tipo de control que revisa la racionalidad de la decisión a la luz de los criterios que se encuentren "en el expediente" ${ }^{33}$; y, finalmente, un tercer tipo de control, todavía incipiente, que se caracteriza por ser más incisivo y por revisar que el juicio de ponderación se ha realizado correctamente ${ }^{74}$.

Evidentemente, el expediente administrativo es una pieza clave en el segundo tipo de control, puesto que consiste precisamente en un juicio de contraste entre la motivación de la decisión y la información del expediente. Sin embargo, el expediente administrativo está también llamado a desempeñ 4ar una función clave en el tercer tipo de control, porque el primer paso para verificar que el juicio de ponderación ha sido correcto es comprobar que dicho juicio se ha realizado sin omitir material ponderable (es decir, que el expediente refleja todas las circunstancias relevantes y que cumple por tanto con el estándar del procedimiento debido). Así, una mayor atención al expediente como categoría dogmática puede contribuir a enriquecer una teoría tan central para la disciplina del derecho administrativo como es la del control de la discrecionalidad.

\section{CONCLUSIÓN}

El análisis desplegado a lo largo de este trabajo ha servido para poner de manifiesto las distintas funciones que el derecho administrativo contemporáneo asigna al expediente administrativo. Por un lado, el expediente administrativo es una pieza clave en el engranaje del que se sirve el derecho administrativo para dirigir la acción formalizada de las Administraciones públicas. Por otro lado, es una herramienta fundamental para el control de la legalidad de la acción administrativa, tanto en su vertiente procedimental como material. En el plano procedimental, el expediente administrativo sirve para constatar la existencia de vicios de procedimiento, pero también para determinar sus consecuencias. En el plano material, el expediente administrativo opera como parámetro de racionalidad y congruencia de la acción administrativa. Además, la propia compleción del expediente es susceptible de control, como consecuencia de las exigencias derivadas del deber de diligencia y de los postulados de las teorías más modernas sobre el control de la discrecionalidad.

El lector habrá observado que he desarrollado estas ideas sin apenas prestar atención al formato del expediente administrativo. Esto puede parecer sorprendente, a la vista del interés que ha suscitado la implantación de la Administración electrónica en la literatura jurídica de los últimos años. Sin embargo, he preferido no mezclar esta cuestión con el análisis de las funciones dogmáticas del expediente administrativo. Lo he hecho así por dos razones. En primer lugar, deslindar ambas cuestiones permite apreciar mejor el significado y la utilidad del concepto material de expediente

72 RODRÍGUEZ DE SANTIAGO, 2016: 187.

73 Ibid: 191.

${ }^{74}$ Ibid.: 193. 
administrativo, que pone el foco sobre el contenido (la información) y no sobre el continente (el soporte). En segundo lugar, esta forma de aproximarse al tema muestra que el valor dogmático del expediente administrativo no está específicamente asociado a la implantación del expediente electrónico. Aclaradas estas ideas, no quiero concluir este trabajo sin hacer alguna referencia, siquiera breve, a esta cuestión.

En mi opinión, la implantación del expediente administrativo electrónico acentúa la importancia del expediente como herramienta de dirección y control de la legalidad de la acción administrativa. Esto se debe a que el expediente administrativo electrónico es más fiable que el expediente tradicional como reflejo de la instrucción de los procedimientos administrativos. Por un lado, la técnica del sellado de tiempo impide la incorporación tardía al expediente de documentos antedatados, ya sea para disimular la omisión de trámites que no fueron realizados antes de la toma de la decisión final o para completar o reforzar retroactivamente la base informativa sobre la cual se apoya dicha decisión ${ }^{75}$. Por otro, la huella digital de los documentos electrónicos dificulta el expurgo o cepillado de expedientes, es decir, la eliminación selectiva de documentos que contienen información contradictoria desde el punto de vista del sentido y contenido de la resolución final (una forma fraudulenta de preconstituir el expediente para facilitar la posterior tarea de motivación y salvar posibles impugnaciones basadas en su falta de racionalidad) ${ }^{76}$. Todo ello refuerza la aptitud del expediente administrativo electrónico para desempeñar eficazmente las funciones que le asigna el derecho administrativo. De ahí que el formato electrónico refuerce la importancia del expediente administrativo en la práctica del derecho administrativo $^{77}$. De ahí también la necesidad de que la teoría del derecho administrativo preste mayor atención a esta figura dogmática.

En este sentido, uno de los retos que tiene por delante la teoría del derecho administrativo es aclarar el papel que está llamado a desempeñar el expediente administrativo en el contexto de la Administración algorítmica y de los procesos de toma decisiones mediante herramientas de inteligencia artificial. El análisis realizado a lo largo de este trabajo ha puesto de manifiesto que el expediente administrativo opera como un eslabón intermedio entre la realidad y las resoluciones administrativas: filtra los datos necesarios para decidir y, al hacerlo, desempeña una importante labor de señalización que permite a los interesados centrar su atención sobre la información efectivamente manejada por la Administración. Solo así pueden desplegar una estrategia eficaz dirigida a matizar, completar o poner en duda la fiabilidad o relevancia

75 MIR PUIGPELAT, 2019: 95.

76 Sobre el problema del expurgo de expedientes: Germán FERNÁNDEZ FARRERES, "Las nuevas leyes de Régimen Jurídico del Sector Público y del Procedimiento Administrativo Común: entre la cosmética y el enredo", Asamblea: revista parlamentaria de la Asamblea de Madrid, núm. 34, 2016, pp. 57-75 (p. 69).

77 En el mismo sentido, Julián VALERO TORRIJOS, "La gestión y conservación del documento administrativo electrónico”, en José Luis BLASCO DÍAZ y Modesto J. FABRA VALS (eds.), El documento electrónico: aspectos juridicos, tecnológicos y archivisticos, Universitat Jaume I, Castellón de la Plana, 2008, pp. 23-72 (p. 54). 
de la información que va a determinar la decisión final. Esta labor de señalización es más importante si cabe en un contexto en el que las decisiones se toman por vía de complejos algoritmos, cuyo resultado depende precisamente de los datos que se les suministren.

Sin embargo, uno de los principales desafíos a los que se enfrenta el derecho administrativo del "Estado automático" 78 o "tecnológico" 79 es el carácter inescrutable de las herramientas más avanzadas de inteligencia artificial ${ }^{80}$. Por un lado, la abundancia de datos que manejan estas herramientas hace que el acceso a los mismos no sea necesariamente útil para las personas potencialmente afectadas por sus resulta$\operatorname{dos}^{81}$. Por otro, el propio funcionamiento de estas herramientas es tan complejo que muchas veces no es ni siquiera posible saber a posteriori cuáles son los datos sobre los que se han apoyado los algoritmos para conducir a un determinado resultado ${ }^{82}$. De ahí que la transparencia y la motivación de las decisiones tomadas mediante herramientas de inteligencia artificial sean dos de las principales preocupaciones de la literatura jurídico-administrativa sobre el tema. El problema tiene muchas aristas, pero algunas de las más complejas son cómo trasladar a esta nueva realidad las garantías que asisten a los interesados a la hora de acceder a e influir sobre la información que maneja la Administración en los procedimientos que les afectan y cómo controlar la adecuación y suficiencia de dicha información. El problema, dicho de otra forma, es qué papel puede y debe desempeñar el expediente administrativo en la era de la Administración algorítmica. Este es probablemente uno de los grandes retos que tiene por delante la teoría del derecho administrativo y otra razón para reivindicar el valor del expediente administrativo como categoría central de la disciplina.

\section{BIBLIOGRAFÍA}

Luis ARROYO JIMÉNEZ, "Ponderación, proporcionalidad y derecho administrativo", Indret: Revista para el Análisis del Derecho, núm. 2, 2009.

Xabier ARZOZ SANTISTEBAN, "La autonomía institucional y procedimental de los Estados miembros en la Unión Europea: mito y realidad”, Revista de Administración Pública, núm. 191, 2013, pp. 159-197.

78 Tomo la expresión de Cary COGLIANESE, Administrative Law in the Automated State", Faculty Scholarship at Penn Law, 2273, 2021: https://scholarship.law.upenn.edu/faculty_scholarship/2273.

79 Tomo la expresión de Danielle K. CITRON, "Technological due process", Washington University Law Review, núm. 85, 2007, pp. 1249-1313.

80 Solon BAROCAS y Andrew SELBST, "The intuitive appeal of explainable machines", Fordham Law Review, núm. 87, 2018, pp. 1085-1139 (p. 1094).

81 Alba SORIANO ARNANZ, "Decisiones automatizadas: problemas y soluciones jurídicas más allá de la protección de datos”, Revista de Derecho Público: Teoría y Método, núm. 3, 2021, pp. 85-127 (p. 95).

${ }^{82}$ Agustí CERRILLO I MARTÍNEZ, "El impacto de la inteligencia artificial en el derecho administrativo ¿nuevos conceptos para nuevas realidades técnicas?", Revista General de Derecho Administrativo, núm. 50, 2019 (sin paginación en la versión electrónica); Coglianese, 2021:8. 
José María BAÑO LEÓN, "Derecho al procedimiento en la relación administrativa multipolar (los derechos fundamentales como límite a la renuncia del legislador al control previo de actuaciones)", Revista Española de Derecho Administrativo, núm. 189, 2018.

Eric BARBIER DE LA SERRE, "Procedural Justice in the European Community Case-law concerning the Rights of the Defence: Essentialist and Instrumental Trends", European Public Law, núm. 12, 2006, pp. 225-250.

Javier BARNES, "Sobre el procedimiento administrativo: evolución y perspectivas", en Javier BARNES (ed.), Innovación y reforma en el derecho administrativo, Global Law Press, Sevilla, 2006.

—, "Administrative Procedure", en Peter CANE, Herwig C.H. Hofmann, Eric C. IP y Peter L. Lindseth (eds.), The Oxford Hadkbook of Comparative Administrative Law, Oxford University Press, Oxford, 2020.

Solon BAROCAS y Andrew SELBST, "The intuitive appeal of explainable machines", Fordham Law Review, núm. 87, 2018, pp. 1085-1139.

Concepción BARRERO RODRÍGUEZ, La prueba en el procedimiento administrativo, Aranzadi, Cizur Menor, 2003.

—, "El procedimiento administrativo común en la Ley de 2015: su estructura", en Luciano PAREJO ALFONSO y Marcos VAQUER CABALLERÍA (dirs.), Estudios sobre el procedimiento administrativo. III Instituciones, Tirant lo Blanch, Valencia, 2020, pp. 165-236.

Margarita BELADÍEZ ROJO, Validez y eficacia de los actos administrativos, Marcial Pons, Madrid, 1994.

Rafael CABALLERO SÁNCHEZ, "La extensión del derecho administrativo y su proyección contencioso-administrativa", Teoría y Método: Revista de Derecho Público, núm. 4, 2021.

Dolors CANALS I AMETLLER, "La actuación de las Administraciones Públicas ante la reciente reforma del procedimiento administrativo común", Revista Jurídica de la Comunidad de Madrid, núm. 2018, 2018.

—, "El ejercicio de potestades administrativas por operadores privados en régimen de mercado", en Eduardo GAMERO CASADO (dir.), La potestad administrativa: concepto y alcance práctico de un criterio clave para la aplicación del derecho administrativo, Tirant lo Blanch, Valencia, 2021, pp. 320387.

Agustí CERRILLO I MARTÍNEZ, "El impacto de la inteligencia artificial en el derecho administrativo ¿̇nuevos conceptos para nuevas realidades técnicas?”, Revista General de Derecho Administrativo, núm. 50, 2019.

César CIERCO SEIRA, La participación de los interesados en el procedimiento administrativo, Publicaciones del Real Colegio de España, Bolonia, 2002.

Danielle K. CITRON, "Technological due process", Washington University Law Review, núm. 85, 2007, pp. 1249-1313.

Cary COGLIANESE, Administrative Law in the Automated State", Faculty Scholarship at Penn Law, 2273, 2021: https://scholarship.law.upenn.edu/faculty_scholarship/2273

Antonio DESCALZO GONZÁLEZ, "La forma en el procedimiento administrativo", en Luciano PAREJO ALFONSO y Marcos VAQUER CABALLERÍA (dirs.), Estudios sobre el procedimiento administrativo. III. Instituciones, Tirant lo Blanch, Valencia, 2020, pp. 237-306.

Eva DESDENTADO DAROCA, "Discrecionalidad administrativa y procedimiento administrativo", en Luciano PAREJO ALFONSO y Marcos VAQUER CABALLERÍA (dirs.), Estudios sobre el procedimiento administrativo. III. Instituciones, Tirant lo Blanch, Valencia, 2020, pp. 83-122.

Ricardo DE VICENTE DOMINGO, La anulación de los actos administrativos por motivos formales, Tirant lo Blanch, Valencia, 2018.

Gabriel DOMÉNECH PASCUAL, "Las irregularidades no invalidantes desde una perspectiva económica", El alcance de la invalidez de la actuación administrativa: Actas del XII Congreso de la Asociación Española de Profesores de Derecho Administrativo, INAP, Madrid, 2017, pp. 151-170.

Mariolina ELIANTONIO y Elise MUIR, "Concluding Thoughts: Legitimacy, Rationale and Extent of the Incidental Proceduralisation of EU Law", Review of European Administrative Law, núm. 8, 2015, pp. 177-204. 
Germán FERNÁNDEZ FARRERES, "Las nuevas leyes de Régimen Jurídico del Sector Público y del Procedimiento Administrativo Común: entre la cosmética y el enredo", Asamblea: revista parlamentaria de la Asamblea de Madrid, núm. 34, 2016, pp. 57-75.

Tomás-Ramón FERNÁNDEZ RODRÍGUEZ, "La doctrina de los vicios de orden público en el contencioso-administrativo: orígenes y evolución", Revista de Administración Pública, núm. 57, 1968, pp. 223-277.

-, "Los vicios de orden público y la teoría de las nulidades en el derecho administrativo", Revista de Administración Pública, núm. 58, 1969, pp. 49-126.

Eduardo GARCÍA DE ENTERRÍA y Tomás-Ramón FERNÁNDEZ, Curso de Derecho Administrativo, Vol. II, 14a ed. Civitas, Madrid, 2015

Javier GARCÍA LUENGO, Las infracciones formales como causa de invalidez del acto administrativo. Un estudio sobre el artículo 48.2 de la Ley 39/2015, Iustel, Madrid, 2016.

Francisco GONZÁLEZ NAVARRO, "Procedimiento administrativo común, procedimientos triangulares y procedimientos complejos", Revista de estudios de la vida local, núm. 211, 1981, pp. 409-454.

Herwig C.H. HOFMANN, "The Duty of Care in EU Public Law - A Principle Between Discretion and Proportionality", Review of European Administrative Law, núm. 13, 2020, pp. 87-112.

Luis MEDINA ALCOZ, "Los hechos en el derecho administrativo. Una aproximación", Revista Española de Derecho Administrativo, núm. 177, 2016, pp. 103-158.

Luis MÍGUEZ MACHO, Marcos ALMEIDA CERREDA Y Diana SANTIAGO IGLESIAS (coord.), La simplificación de los procedimientos administrativos, Actas del IX Congreso de la AEPDA, 2014.

Oriol MIR PUIGPELAT, Transparencia y procedimiento administrativo. El derecho de acceso al expediente y su conexión con el derecho de acceso a información pública, Civitas, Madrid, 2019.

Ángel M. MORENO MOLINA, "Los vicios del procedimiento administrativo y su control judicial", en Luciano PAREJO ALFONSO y Marcos VAQUER CABALLERÍA (dirs.), Estudios sobre el procedimiento administrativo. III. Instituciones, Tirant lo Blanch, Valencia, 2020, pp. 307-399.

H. Peter NEHL, "Good administration as procedural right and/or general principle?", en Herwig C.H. HOFMANN and Alexander TÜRK (eds.), Legal challenges in EU administrative law: towards an integrated administration, Edward Elgar, Cheltenham, 2009, pp. 322-351.

Luciano PAREJO ALFONSO, La vigilancia y la supervisión administrativas. Un ensayo de su construcción como relación jurídica, Tirant lo Blanch, Valencia, 2016.

—, "Organización y procedimiento administrativos", en Luciano PAREJO ALFONSO y Marcos VAQUER CABALLERÍA (dirs.), Estudios sobre el procedimiento administrativo. III Instituciones, Tirant lo Blanch, Valencia, 2020, pp. 27-52.

Juli PONCE SOLÉ, Deber de buena administración y derecho al procedimiento administrativo debido. Las bases constitucionales del procedimiento administrativo y del ejercicio de la discrecionalidad, Lex Nova, Valladolid, 2000.

-, La lucha por el buen gobierno y el derecho a una buena administracion mediante el estándar jurídico de diligencia debida, Cátedra de Democracia y Derechos Humanos (Universidad de Alcalá y Defensor del Pueblo), Alcalá de Henares, 2019

Ricardo RIVERO ORTEGA, El expediente administrativo. De los legajos a los soportes electrónicos, 2a ed. Cizur Menor, Aranzadi, 2008.

José María RODRÍGUEZ DE SANTIAGO, La ponderación de bienes e intereses en el Derecho administrativo, Marcial Pons, Madrid, 2000.

—, La Administración del Estado social, Marcial Pons, Madrid, 2007.

—, Metodología del derecho administrativo. Reglas de racionalidad para la adopción y control de la decisión administrativa, Marcial Pons, Madrid, 2016.

Francisco Javier SANZ LARRUGA, "Gestión documental”, en Eduardo GAMERO CASADO (dir.), Tratado de procedimiento administrativo común y régimen jurídico básico del sector público, Tirant lo Blanch, Valencia, 2017, pp. 913-995.

Eberhard SCHMIDT-ASSMANN, La teoría general del derecho administrativo como sistema, Marcial Pons, Madrid, 1993.

Alba SORIANO ARNANZ, "Decisiones automatizadas: problemas y soluciones jurídicas más allá de la protección de datos", Revista de Derecho Público: Teoría y Método, núm. 3, 2021, pp. 85-127. 
Dolores UTRILLA FERNÁNDEZ-BERMEJO, "La relación jurídica en el sistema de derecho administrativo", Revista de Derecho Público: Teoría y Método, núm. 2, 2020, pp. 73-118.

Patricia VALCÁRCEL FERNÁNDEZ, "Documentos y archivos electrónicos", en José Luis PIÑAR MAÑAS, Administración electrónica y ciudadanos, Civitas, Madrid, 2011.

Julián VALERO TORRIJOS, "La gestión y conservación del documento administrativo electrónico", en José Luis BLASCO DÍAZ y Modesto J. FABRA VALS (eds.), El documento electrónico: aspectos jurídicos, tecnológicos y archivísticos, Universitat Jaume I, Castellón de la Plana, 2008, pp. 23-72.

Marcos VAQUER CABALLERÍA, "La codificación del procedimiento administrativo en España", Revista General del Derecho Administrativo, núm. 42, 2016.

—, “¿Para qué sirve el procedimiento administrativo?”, en Luciano PAREJO ALFONSO y Marcos VAQUER CABALLERÍA (dirs.), Estudios sobre el procedimiento administrativo. III Instituciones, Tirant lo Blanch, Valencia, 2020, pp. 53-82.

Francisco VELASCO CABALLERO, "El acto administrativo: concepto, clases y contenido", en Eduardo GAMERO CASADO (dir.), Tratado de procedimiento administrativo común y régimen jurídico básico del sector público, Tirant lo Blanch, Valencia, 2017, pp. 1757-1799.

Diego VERA JURADO, "Cuestiones generales del procedimiento administrativo", en Eduardo GAMERO CASADO (dir.), Tratado de Procedimiento Administrativo Común y Régimen Jurídico Básico del Sector Público, Tirant lo Blanch, Valencia, 2017, pp. 1273-1309. 